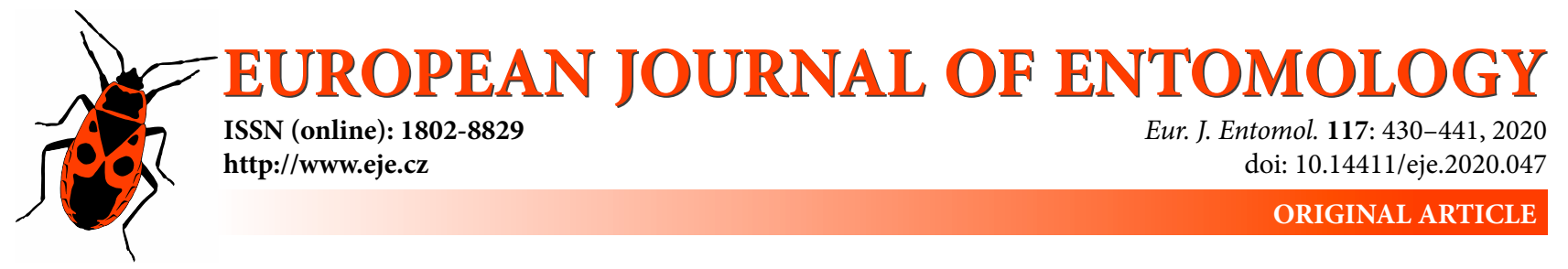

\title{
Feeding habits of the endangered Japanese diving beetle Hydaticus bowringii (Coleoptera: Dytiscidae) larvae in paddy fields and implications for its conservation
}

\author{
ReIYA WATANABE ${ }^{1}$, SHIN-YA OHBA ${ }^{2}$ and TomOYUKI YOKOI ${ }^{3}$ \\ ${ }^{1}$ Environmental Technology Division, Institute of Environmental Informatics, IDEA Consultants Inc., 2-2-2 Hayabuchi, \\ Tsuzuki-ku, Yokohama, Kanagawa 224-0025, Japan; ORCID: https://orcid.org/0000-0002-3098-9206; \\ e-mail: watanabe.reiya.sw@alumni.tsukuba.ac.jp \\ ${ }^{2}$ Faculty of Education, Nagasaki University, Nagasaki, Japan; e-mail: ooba@nagasaki-u.ac.jp \\ ${ }^{3}$ Graduate School of Life and Environmental Sciences, University of Tsukuba, Ibaraki, Japan; \\ e-mail: yokoi.tomoyuki.gp@u.tsukuba.ac.jp
}

Key words. Coleoptera, Dytiscidae, Hydaticus bowringii, diving beetle, larva, feeding, tadpole, paddy field, phenology, conservation, Japan

\begin{abstract}
The diving beetle Hydaticus bowringii Clark, 1864 (Coleoptera: Dytiscidae) is on the Red List of Japan as 'Near Threatened'. However, there is no quantitative information on the feeding habits of its larvae, which could be used to aid its conservation. In order to determine the prey that are important for the survival and growth of larvae of $H$. bowringii, we combined the results of field surveys of paddy fields and rearing experiments. In the field, $H$. bowringii larvae predominantly feed on tadpoles of five species of frogs and occasionally also on insects, loaches and worms. The phenology of the tadpoles was similar to that of larvae of $H$. bowringii, as their abundances increased from May to June and decreased in July. Experimentally reared larvae of $H$. bowringii grew faster when fed tadpoles than when fed Sigara nymphs or a mixture of both prey, and more emerged as adults when tadpoles were included in their diet. Adults were larger in the tadpole treatment than in the Sigara treatment. Based on these results, we conclude that tadpoles are more suitable prey for the survival and growth of larvae of $H$. bowringii than insects. The decline in the abundance of frogs could be one of the factors determining the decrease in the local abundances of $H$. bowringii. In conclusion, we affirm that in order to conserve populations of $H$. bowringii it is crucial to maintain paddy field environments in which frogs are abundant.
\end{abstract}

\section{INTRODUCTION}

Diving beetles (Coleoptera: Dytiscidae) are top predators, especially in shallow and fishless wetlands, such as paddy fields (Cobbaert et al., 2010; Ohba, 2011). Both the larvae and adults are carnivorous. The larvae are exclusively predatory, whereas adults also scavenge for food (Culler et al., 2014). They prey on zooplankton, insects, horsehair worms, gastropods, fish, amphibians and reptiles (Culler et al., 2014; Watanabe, 2019). They are often used as indicators of biodiversity in freshwater environments worldwide (Foster \& Bilton, 2014) and also in Japanese paddy fields (MAFF \& NARO, 2012). In Japan, approximately $46 \%$ (60/131 species) of the species of diving beetles inhabit paddy fields, which also include agricultural ditches and irrigation ponds (Saijo, 2001; Mitamura et al., 2017; Watanabe et al., 2019; Nakajima et al., 2020) and 45\% (27/60 species) of them are on the Red List of Japan (Ministry of the Environment of Japan, 2019). The diversity of diving beetles is declining in paddy fields because of farmland consolidation, increased abandonment of paddy fields and the use of pesticides and herbicides (Nishihara et al., 2006; Ohba, 2011).

Diving beetle larvae prefer different types of prey (Johansson \& Nilsson, 1992; Tate \& Hershey, 2003; Ohba, 2009a, b; Klecka \& Boukal, 2012; Yee et al., 2013) and the type of prey can affect their growth and survival (Culler \& Lamp, 2009; Ohba, 2009a, b; Nishihara, 2012; Ohba \& Inatani, 2012). Therefore, it is important for their conservation to clarify their feeding habits.

Previous studies on the feeding habits of endangered Japanese diving beetles [Cybister brevis Aubé, 1838, C. chinensis Motschulsky, 1854, C. tripunctatus lateralis (Fabricius, 1798) and Dytiscus sharpi (Wehncke, 1875)] are important for their conservation (Inoda et al., 2009; Ohba, 2009a, b; Nishihara, 2012; Ohba \& Inatani, 2012). In the case of D. sharpi, Asellus hilgendorfi hilgendorfi Bovallius, 1886 is its main prey, the growth of which can be promoted by adding hardwood litter to paddy fields. As 

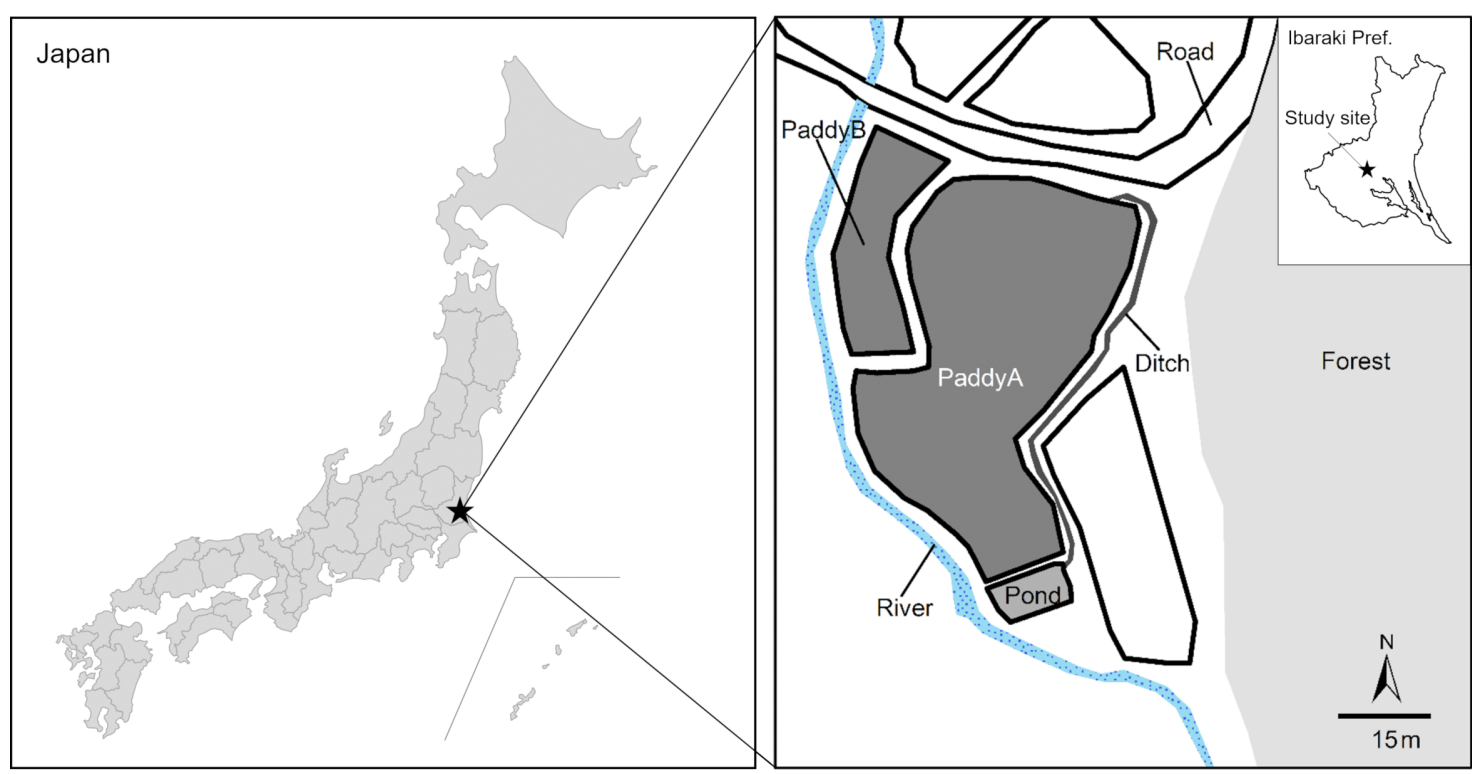

Fig. 1. Maps showing the location of the site studied at Ishioka City, Ibaraki Prefecture, Japan. White polygons indicate paddy fields that were not surveyed.

a result of which, the abundance of $D$. sharpi increases (Nishihara, 2012).

Hydaticus bowringii Clark, 1864 (Coleoptera: Dytiscidae) is another endangered diving beetle in Japan, which on the Red List of Japan is listed as 'Near Threatened' (Ministry of the Environment of Japan, 2019). It is distributed widely in Japan, China, Korea and Taiwan (Mori \& Kitayama, 2002). This species is considered to be univoltine (Tsuzuki et al., 2003), although there is no quantitative field survey for this species. From spring to early autumn (i.e. late April to September), adults occur in paddy fields and irrigation ponds, and their larvae can be found in paddy fields (Saijo, 2001; Watanabe, 2017a). Adults leave water bodies from late autumn to early spring (i.e. October to early April) and probably overwinter on land (Mori \& Kitayama, 2002) as overwintering adults have been found resting on mud at the base of water plants growing along the shores of drained irrigation ponds (Watanabe, 2017b).

Very little is known about the ecology of the larvae of $H$. bowringii. They have been observed feeding on tadpoles in the field and on chironomid (Diptera) larvae in the laboratory (Tsuzuki et al., 2003; Watanabe, 2017a), which may be an opportunistic option for survival in the laboratory and not necessarily a common prey in nature. However, there is no quantitative information about the larval diet of this species to guide its conservation. In the present study, we identify the important species of prey for the survival and growth of larvae of $H$. bowringii by using field surveys and rearing this species in the laboratory. We use the results to discuss its habitat requirements in paddy fields necessary for maintaining thriving populations of $H$. bowringii.

\section{MATERIALS AND METHODS}

\section{Study sites}

Field surveys were conducted in two adjacent paddy fields, Paddy A (surface area $1,698 \mathrm{~m}^{2}$, linear perimeter $193 \mathrm{~m}$ ) and Paddy B (surface area $309 \mathrm{~m}^{2}$, linear perimeter $88 \mathrm{~m}$ ) in Ishioka
City, Ibaraki Prefecture, Japan from 10 May to 31 August 2018 and 26 April to 31 August 2019 (Fig. 1). Mean \pm SD water depth was $6.18 \pm 2.38 \mathrm{~cm}$ (range $1.0-12.6 \mathrm{~cm}$ ) in Paddy A and 6.04 $\pm 2.67 \mathrm{~cm}(1.3-14.0 \mathrm{~cm})$ in Paddy B. The landscape surrounding the sites studied was dominated by paddy fields and forests, with few other wetlands (i.e. rivers, abandoned paddy fields and ponds). Paddy fields were flooded from late April to late August in both 2018 and 2019. Paddy A was connected to a traditional earth ditch, whereas Paddy B was not. No insecticides or herbicides were applied in either paddy field during the study period. There was an abundance of water plants in addition to planted rice, including Eleocharis kuroguwai Ohwi, Monochoria vaginalis (Burm.f.) C. Presl ex Kunth, Murdannia keisak (Hassk.) Hand.-Mazz., Oenanthe javanica (Blume) DC. and Persicaria thunbergii (Siebold et Zucc.) H.Gross at both sites. On June 2, 29 and July 17, 2018 and on June 1, 16 and July 8, 2019, weeding was carried out in paddy fields using a hand-operated weeding machine. No surveys were conducted on these days as the water was turbid and unsuitable for observation.

\section{Feeding habits and phenology of larvae of $\boldsymbol{H}$. bowringii}

Nocturnal observations of the paddy fields were carried out at 1-9 day intervals from May to August 2018 and 2019 (47 times in 2018 and 42 times in 2019). Following previous studies, (Ohba, 2009a, b) these observations lasted a few hours between 20:00-2:00 h, but not on rainy days. We searched for larvae of $H$. bowringii using a $400 \mathrm{~lm}$ flashlight (MG-186R, GENTOS, Tokyo) while walking at a constant speed $(3 \mathrm{~m} / \mathrm{min})$ in the same direction on the levee around the paddy fields. The number of larvae within $1.5 \mathrm{~m}$ of the levee edge during one round of each paddy field was recorded. When we saw a hunting event, both the larva and the prey were captured using a D-frame net $(30 \mathrm{~cm}$ width, $1 \mathrm{~mm}$ mesh size). Each larva of $H$. bowringii was placed in a plastic container ( $7.5 \mathrm{~cm}$ width, $10.5 \mathrm{~cm}$ long, $3.5 \mathrm{~cm}$ deep) attached to a ruler and photographed. Head widths of larvae were measured using ImageJ software (Abràmoff et al., 2004) was used as a measure of body length (Johansson \& Nilsson, 1992; Ohba, 2009a). Then, the larva was released back into the paddy field from which it was captured. The prey was preserved in $80 \%$ ethanol and brought to the laboratory for identification and measurement. The prey species were identified based on Mukai 
(a)

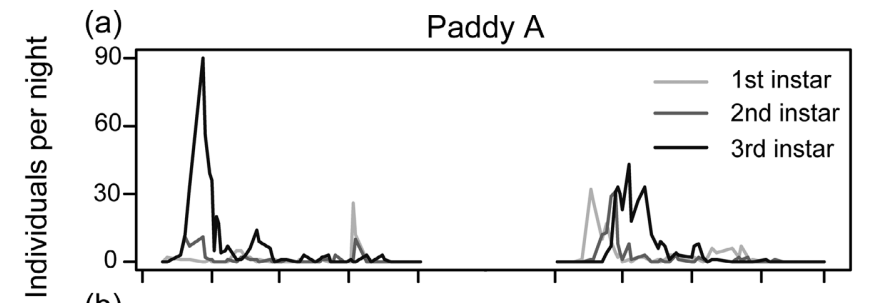

(b)

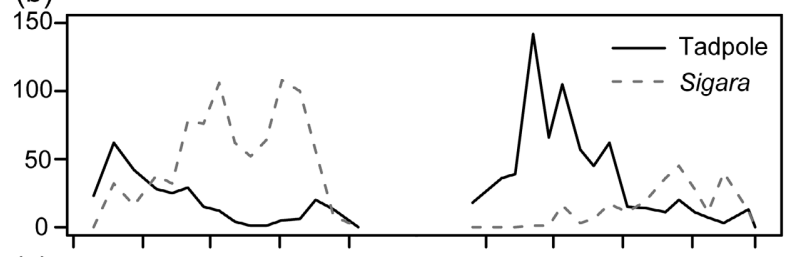

(c)

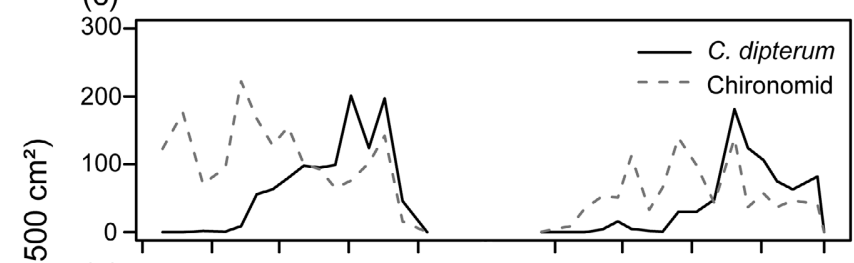

(d)

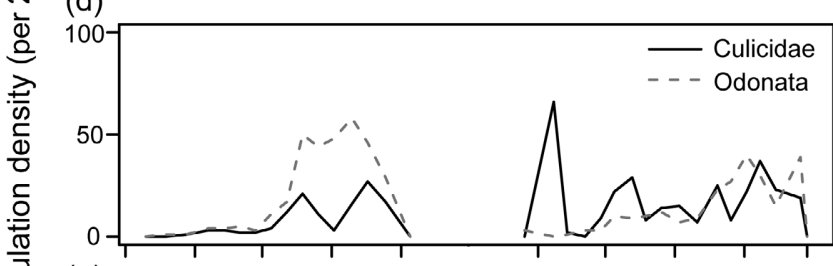

(e)

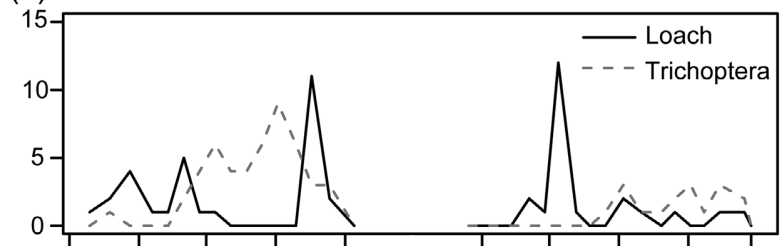

(f)

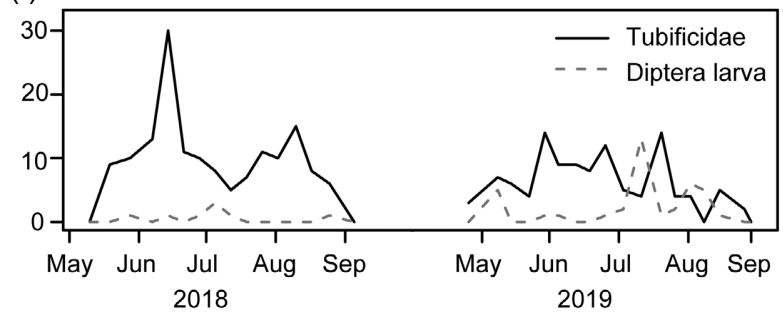

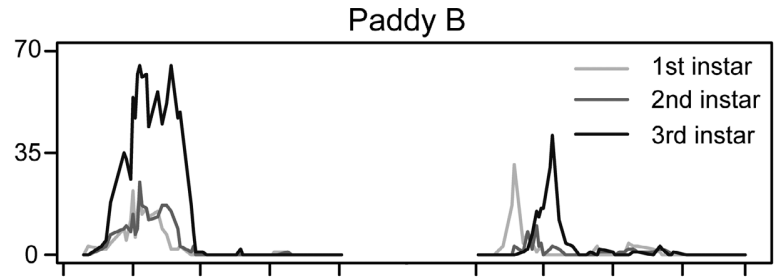
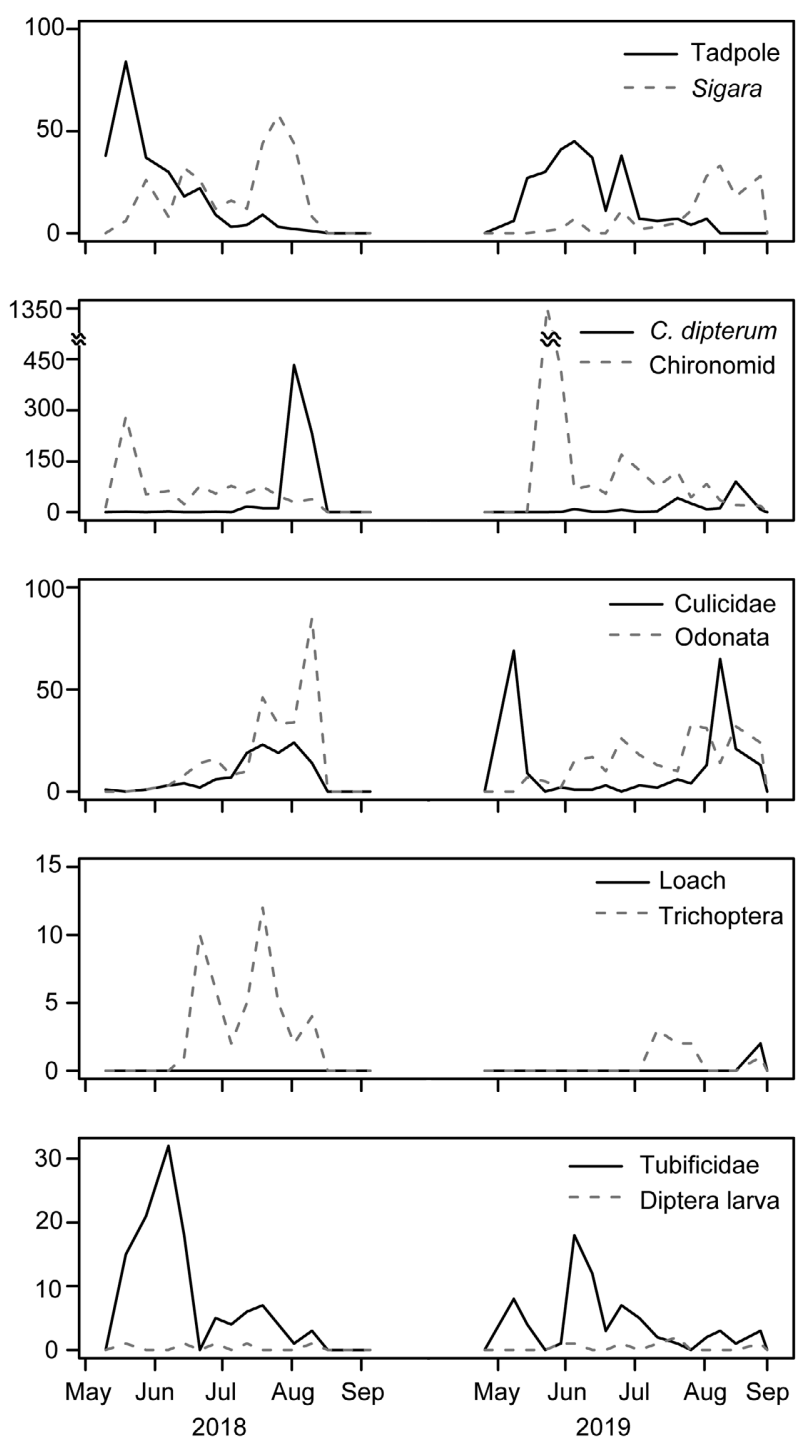

Date

Fig. 2. Seasonal changes in the population density at the two sites in 2018 and 2019: (a) larvae of Hydaticus bowringii, (b) tadpoles and Sigara spp., (c) Cloeon dipterum nymphs and chironomid larvae, (d) larvae of Culicidae and odonate nymphs, (e) loaches and larvae of Trichoptera and (f) Tubificidae and larvae of Diptera.

(2014), Matsui \& Maeda (2018) and Kawai \& Tanida (2018), and their body widths measured using a Nikon Multi Zoom AZ100M stereomicroscope (Nikon, Tokyo) and microscope imaging software (NIS-Elements 4.2.0, Nikon, Tokyo).

\section{Quantification of potential prey}

To determine the phenology and abundance of potential prey, we conducted field surveys once a week from May to August 2018 and late April to August 2019 at both paddy fields. We placed a quadrat ( $25 \mathrm{~cm}$ vertical, $20 \mathrm{~cm}$ horizontal, $20 \mathrm{~cm}$ height) at five random locations near the edge of the levee and swept five times within the quadrat using a square-framed net $(15 \mathrm{~cm}$ by 12 $\mathrm{cm}$ with $0.5 \mathrm{~mm}$ mesh size) (bl-g1, Mitani-Turigyogu, Saitama).
We swept inside the quadrat, including the surface of the mud. The samples were transferred to a white plastic tray and all the sufficiently large animals (> approximately $3 \mathrm{~mm}$ ) were sorted, counted, identified to the lowest possible taxon and released at the site. Prey that could not be identified in the field were preserved in $80 \%$ ethanol and brought to the laboratory for identification using the keys of Mukai (2014), Matsui \& Maeda (2018) and Kawai \& Tanida (2018).

\section{Rearing experiment: Effect of diet}

To compare the effect of potential prey on the survival and growth of larvae of $H$. bowringii, we reared them in a laboratory from May to July 2019. The field survey in 2018 revealed that 
H. bowringii mainly feed on tadpoles of the Japanese tree frog, Dryophytes japonica (Günther, 1859) (see Table 2). Among insects, larvae of $H$. bowringii attacked Sigara nymphs in the field (Table 2) that were abundant at both sites when the larvae of $H$. bowringii were present (Fig. 2). Therefore, we used D. japonica tadpoles and Sigara nymphs; mostly those of S. septemlineata (Paiva, 1918), but also some S. nigroventalis (Matsumura, 1905) as prey. Although chironomid larvae were also abundant and attacked by larvae of $H$. bowringii, we did not use them as prey because they are usually buried in mud. Tadpoles and Sigara nymphs were collected from paddy fields at the Tsukuba-Plant Innovation Research Centre, in Tsukuba City and Ishioka City.

To obtain first instar larvae, we collected adult females of $H$. bowringii from paddy fields in Ishioka City from May to June 2019 and kept them individually in plastic cups $(12.9 \mathrm{~cm}$ diameter, $6.5 \mathrm{~cm}$ deep) containing $200 \mathrm{ml}$ dechlorinated tap water. The cups containing larvae were kept at $25^{\circ} \mathrm{C}$ and under a $14 \mathrm{~L}$ : $10 \mathrm{D}$ photo cycle in an incubator (Bio Multi Incubator, Nippon Medical \& Chemical Instruments, Osaka). The temperature used was based on the average temperature from June to August 2018 in the study area (i.e. $25.3^{\circ} \mathrm{C}$, Japan Meteorological Agency (2020)). Plastic mesh (16.5 $\mathrm{cm}$ by $5 \mathrm{~cm}$ with $3 \mathrm{~mm}$ mesh) in the plastic cups served as an oviposition substrate and was checked for the presence of eggs daily. When eggs were found, the mesh with eggs was moved to another plastic cup containing $200 \mathrm{ml}$ of water. We checked the eggs daily and transferred hatchlings to individual rearing cages $(88 \mathrm{~mm} \times 88 \mathrm{~mm} \times 52 \mathrm{~mm})$.

The experimental design followed that of Ohba (2009a, b). Rearing cages were placed in a plastic container $(91.1 \mathrm{~cm} \times 61.1$ $\mathrm{cm} \times 20.3 \mathrm{~cm}$ ) with two filtration devices (Suisaku Eight Flower $\mathrm{S}$, Suisaku, Tokyo). To prevent the water in the rearing cages from fouling, a $3 \times 3 \mathrm{~cm}$ hole was made in the bottom of each rearing cage, and a 1-mm polyethylene mesh covered the hole to allow the water to move between the plastic container and rearing cages. We placed a $1-\mathrm{cm}$ layer of river gravel $(2-3 \mathrm{~mm}$ in size; Happiness Chuume, Stone Dealer Shinsei, Osaka) on the mesh. Water depth in rearing cages was kept at $2 \mathrm{~cm}$ above the gravel layer ( $3 \mathrm{~cm}$ for third instar larvae). In addition, a 5 -cm long piece of an aquatic plant, Ceratophyllum demersum L., was placed in each rearing cage as a perch for the larvae.

Tadpole, Sigara and tadpole-Sigara mixed diet were the three experimental diets. In the tadpole treatment $(n=21)$, six small tadpoles (1.4-2.0 cm snout-vent length, SVL) were provided daily for the first instar larvae, six medium tadpoles $(2.1-2.5 \mathrm{~cm}$ SVL) for second instar larvae and six large tadpoles (2.6-3.2 cm SVL) for third instar larvae. In the Sigara treatment $(\mathrm{n}=19)$, 10 individuals of 4-5th instar nymphs $(4.0-5.0 \mathrm{~mm}$ total body length) were provided daily for first instar larvae, 10 adults (5.0$6.0 \mathrm{~mm}$ ) for second instar larvae and 20 adults for third instar larvae. In the tadpole-Sigara mixed diet treatment $(\mathrm{n}=12)$, six small tadpoles or six Sigara nymphs were provided daily for first instar larvae, six medium tadpoles or six Sigara adults fore second instar larva and six large tadpoles or 10 Sigara adults for third instar larvae, and the species of prey alternated every 2 days beginning with tadpoles. Some of the first instar larvae moulted to the second instar within 2 days and were not fed Sigara nymphs.

Based on the preliminary tests, the number of prey provided daily in each treatment was sufficient for the larvae to be satiated. We checked the rearing cages daily and recorded both the survival and development of the larvae of $H$. bowringii and number of prey consumed. Dead prey were removed and replaced with new prey daily to maintain a constant prey density. Third instar larvae just before pupation often swam hurriedly and tried to climb the walls of the rearing cage (Watanabe, pers. observ.). Larvae that showed such behaviour were checked again $2 \mathrm{~h}$ after feeding and those that did not eat any prey were moved to a plastic cup $(88$ $\mathrm{mm} \times 88 \mathrm{~mm} \times 52 \mathrm{~mm}$ ) with wet peat moss for pupation (Ohba 2009a, b). The day when the larva made the pupal chamber in the moss was defined as the final day of the larval period. We also recorded the pupal period for each individual, i.e. interval between the construction of the pupal chamber and adult emergence.

When an adult emerged, its sex, total body length and wet weight were recorded. Total body length and wet weight were measured using a calliper $(0.1 \mathrm{~mm}$ precision, Pocket Vernier Caliper, Shinwa Rules, Niigata) and an electronic balance (0.01 mg precision, HR-202i, A \& D Company, Limited, Tokyo), respectively. To compare the effect of different prey on beetle development, we also recorded the total body length of adults of H. bowringii ( 53 males and 46 females) collected from the study sites between May and July 2019. We visually searched for adults at night and collected them using a D-frame net. After the adults were measured, they were released.

\section{Statistical analysis}

The statistical software R version 3.6.0 (R Core Team, 2019) was used for all analyses. To compare the diets of the larvae of different instars of $H$. bowringii, their diet was classified into three prey categories: tadpole (including frog eggs), loach and invertebrate. Then, we used multinomial logit models (MLM) with prey category as a response variable, and the larval instar of H. bowringii, the site (i.e. Paddy A or Paddy B), and year as explanatory variables ('brglm2' package, Kosmidis et al., 2020). We created models with all possible combinations of explanatory variables and regarded the model with lowest Akaike's information criterion (AIC) as the best model.

To determine the predator-prey size relationship in the field $(\mathrm{n}=136)$, we used multiple linear regression models (MLRM) with $\log _{10}$-transformed prey body width as the response variable and the $\log _{10}$-transformed head width of larvae of $H$. bowringii, the site and prey category as explanatory variables. We created models with all possible combinations of explanatory variables and regarded the model with lowest value of AIC as a best model ('MASS' package, Ripley et al., 2020). Cases in which several larvae were feeding on a single item of prey were not included in these analyses. We also used a one-way analysis of variance (ANOVA) to compare the $\log _{10}$-transformed head widths of larvae of $H$. bowringii at the different sites.

To assess the prey preferences of larvae of $H$. bowringii for three categories of prey, we calculated the Manly's alpha $(\alpha)$ (Chesson, 1978):

$$
\alpha_{i}=\frac{r_{i}}{p_{i}} / \sum_{i=1}^{m} \frac{r_{i}}{p_{i}}
$$

where $r_{i}$ is the proportion of prey category $i$ in the diet, $p_{i}$ is the proportion of prey category $i$ in the environment, and $m$ is the total number of categories of prey in the environment (paddy A: $m=3$, paddy B: $m=2$ ). In Paddy B, since there was no predation on loach, we could not calculate $\alpha$ for loach. We summarized the field predation events and the prey abundance in terms of periods of high (May to June) and low (July to August) tadpole abundance in each year and paddy field to calculate $\alpha_{i}$ ('electivity' package, Quintans, 2019). Since the proportions of different categories of prey in the diet of larvae of $H$. bowringii did not differ among instars (see below), we pooled the field predation events for all instars. Values of $\alpha_{i}$ range between 0 (avoidance) and 1 (preference). For visualization, values of $\alpha_{i}$ were converted into electivity indices according to Chesson (1983). When the value of the electivity index equals 0 , the prey category is consumed in proportion to the abundance in the environment, positive values 
indicate preference and negative values indicate avoidance of a prey category.

To assess the correlation between population density of larvae of $H$. bowringii (instars pooled) and that of their potential prey at each site, we calculated the Spearman's rank correlation coefficient using the data on population density summarized for each month; number of larvae of $H$. bowringii recorded per night; total number of each prey taxa recorded in four surveys per month.

We used a two-way ANOVA to determine differences in the developmental period from hatching to emergence of the adults of both sexes and in the different treatments. In addition, the Tukey-Kramer HSD test was used to compare the developmental periods between treatments. To determine if emergence success differed between treatments and sexes, we used Firth's bias-reduced penalized likelihood logistic regression ('logistf' package, Heinze et al., 2018). Using this method, it is possible to estimate the parameters in a logistic regression even for small samples in which separation occurs (Heinze \& Schemper, 2002). In the model, 'normally emerged or not' was the response variable, and sex and treatment (tadpole, Sigara, or tadpole-Sigara mixture) were included as explanatory variables. Model significance was assessed using a penalized likelihood ratio test. To compare the total body length and wet weight of newly emerged adults by sex and treatment, we used a two-way ANOVA followed by the Tukey-Kramer HSD test. To determine the association between type of prey and the adult size of $H$. bowringii, total body length was also compared with that of wild-caught individuals. Since the wet weight of wild-caught individuals varied because of differences in the development of their reproductive organs and level of satiation, we did not compare the wet weights of the reared and wild-caught individuals.

\section{RESULTS}

\section{Phenology of larvae of Hydaticus bowringii and their potential prey}

Larvae of Hydaticus bowringii were recorded from May to August 2018 and 2019 (Fig. 2a). The number of larvae peaked in May and decreased rapidly in June in both years, with a more or less visible second peak in August. Seasonal dynamics of tadpoles (D. japonica, Rana japonica Boulenger, 1879, Pelophylax porosus (Cope, 1868), Glandirana rugosa (Temminck \& Schlegel, 1838), and Zhangixalus
Table 1. Pairwise correlations between the population density of larvae of $H$. bowringii and that of different types of prey at the two sites. Asterisk indicates statistical significance of the Spearman's correlation coefficient $\left({ }^{*} p<0.05,{ }^{* *} p<0.01\right)$.

\begin{tabular}{lcc}
\hline Prey & Paddy A & Paddy B \\
\hline Tadpole & $0.93^{* *}$ & $0.76^{*}$ \\
Sigara spp. & -0.67 & -0.48 \\
Cloeon dipterum nymph & $-0.74^{*}$ & $-0.79^{*}$ \\
Chironomid larva & -0.02 & 0.40 \\
Culicidae larva & -0.17 & -0.62 \\
Odonate nymph & $-0.81^{*}$ & $-0.86^{*}$ \\
Loach & 0.43 & -0.58 \\
Trichoptera larva & $-0.83^{*}$ & -0.27 \\
Tubificidae & 0.26 & 0.64 \\
Diptera larva & -0.43 & 0.32 \\
\hline
\end{tabular}

schlegelii (Günther, 1858)) was similar to that of larvae of $H$. bowringii (Fig. 2b). Population densities of larvae of $H$. bowringii and tadpoles were positively correlated at both sites (Table 1). Abundance of tadpoles increased from May to June and decreased in July. Conversely, population density of larvae of $H$. bowringii was negatively correlated with that of nymphs of Cloeon dipterum and odonate nymphs at both sites and larvae of Trichoptera in Paddy A (Table 1). Sigara spp. (S. septemlineata, S. matsumurai Jaczewski, 1968 and $S$. nigroventralis), Cloeon dipterum (Linnaeus, 1761), odonate nymphs (Orthetrum spp., Ischnura spp., Indolestes peregrinus (Ris, 1916), Lestes temporalis Selys, 1883, Mortonagrion selenion Ris, 1916 and Anax parthenope (Sélys, 1839)), larvae of Trichoptera and Diptera (Syrphidae, Tabanidae and Tipulidae) peaked in density from July to August in both years (Fig. 2b-f). Chironomid larvae were always abundant during the period studied with a peak in May (Fig. 2c). There were two peaks in the abundance of larvae of Culicidae, one in May and the other in August 2019, whereas there was only one peak in May 2018 (Fig. 2d). Abundance of loaches (Misgurnus anguillicaudatus (Cantor, 1842) and Lefua echigonia Jordan \& Richardson, 1907) increased from May to June and August, and that of Tubificidae peaked in May 2018 and June 2019 (Fig. 2e, f).

Table 2. List of the prey captured by larvae of Hydaticus bowringii at both sites and years. Figures in columns are the percentages of each prey captured by each instar ( $n=$ number of records for each instar). '-' indicates not observed.

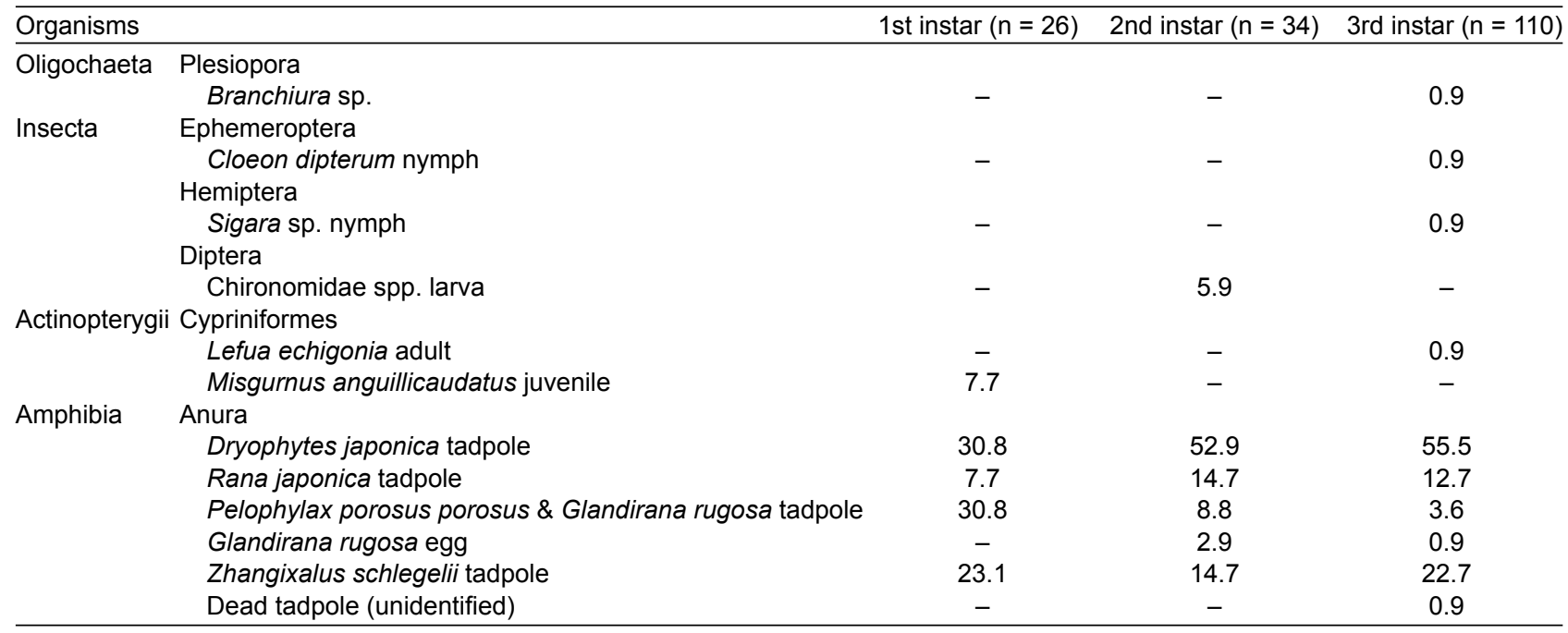



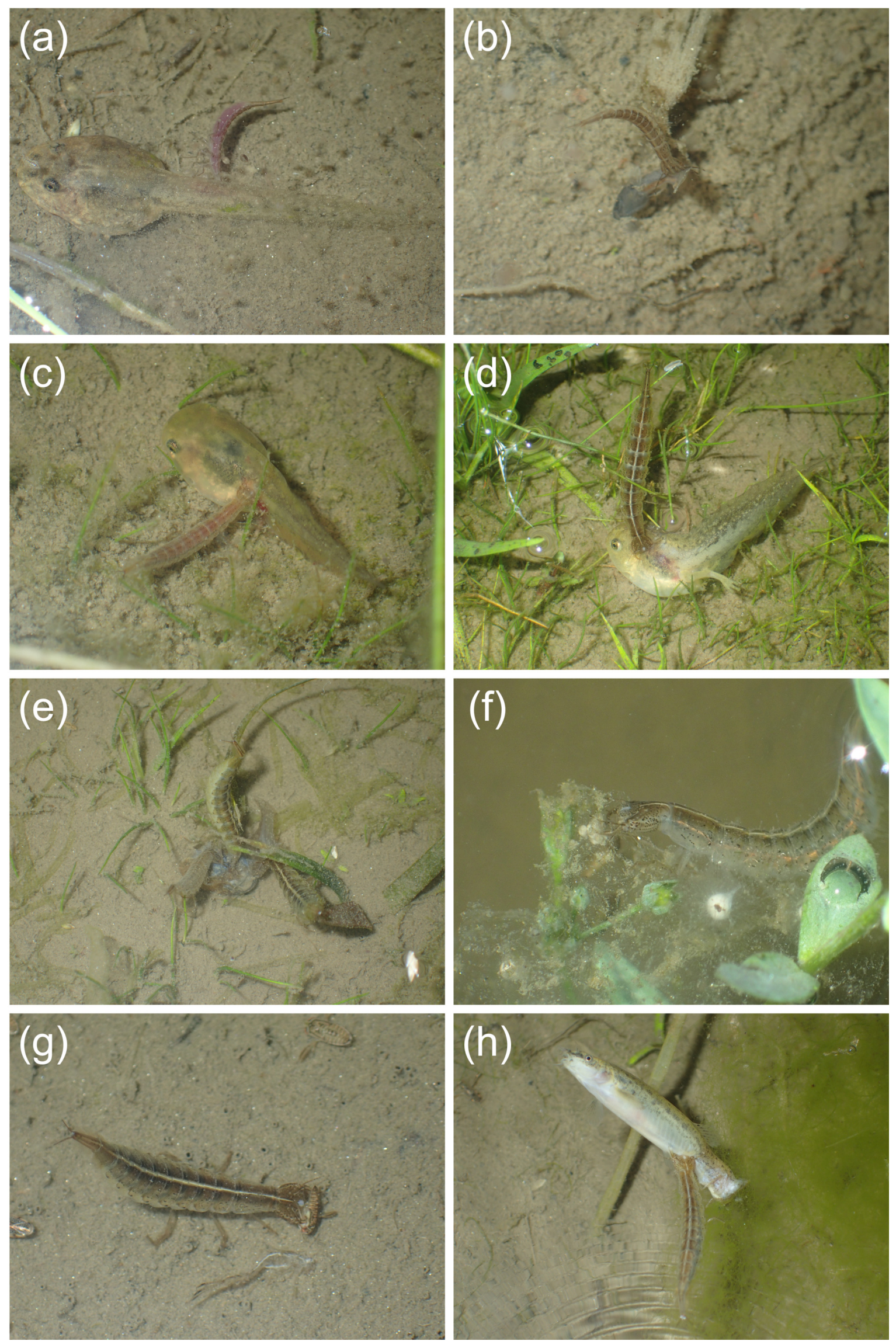

Fig. 3. Photographs of larvae (instar in parentheses) of Hydaticus bowringii feeding on (a) Pelophylax porosus tadpole (second instar), (b) Misgurnus anguillicaudatus juvenile (first instar), (c) Dryophytes japonica tadpole (second instar), (d) D. japonica tadpole (third instar), (e) Zhangixalus schlegelii tadpole (second instar and two third instars), (f) Glandirana rugosa egg (third instar), (g) Sigara sp. nymph (third instar), (h) Lefua echigonia adult (third instar). 


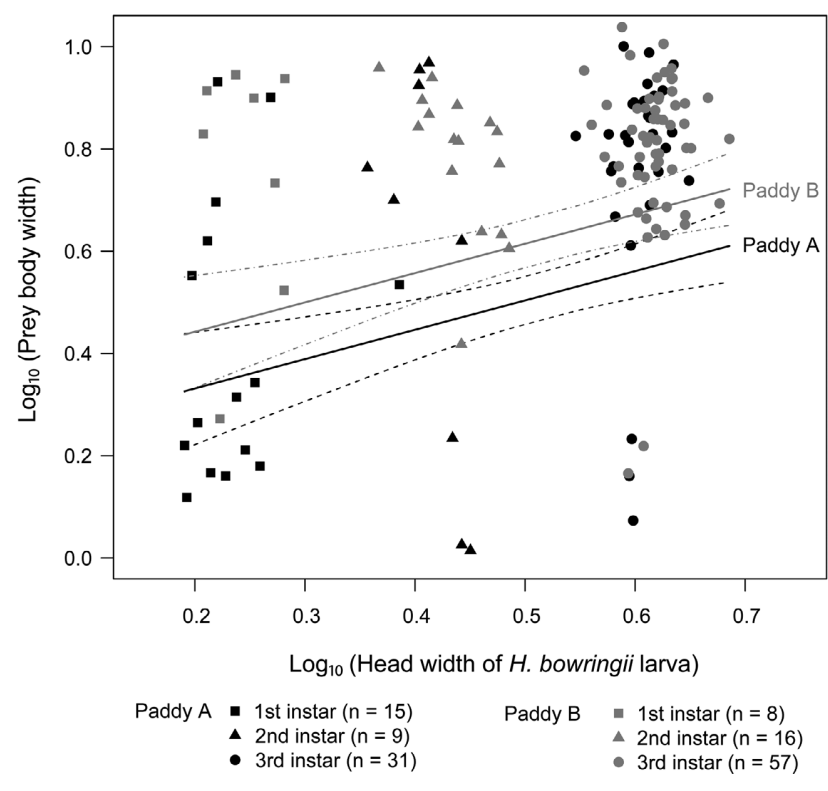

Fig. 4. Relationship between the head width of larva of Hydaticus bowringii and the body width of their prey at the two sites. The regression lines and its $95 \%$ confidence intervals are based on $\operatorname{MLRM}(p<0.0001)$.

\section{Larval diet in the field}

The null model was selected as the best model of the diet composition of larvae of $H$. bowringii and revealed that it is not associated with larval instar, site or year. All larvae mainly consumed tadpoles of the five frog species and loaches, and insects and Tubificidae made up $<6 \%$ of their diet (Table 2, Fig. 3). Larvae of $H$. bowringii other than the first instar were the most frequently recorded eating tadpoles of Dryophytes japonica, followed by those of Zhangixalus schlegelii. In a few cases, several beetle larvae were recorded feeding on the same prey individual (Fig. 3e). The second and third instar larvae also fed on frog eggs laid on the stems of water plants (Fig. 3f). We observed a larva thrusting its head into a jelly-covered frog egg mass and grasping an egg with its mandibles. In Paddy A, larvae of $H$. bowringii consistently preferred tadpoles along with loach in July to August 2018 and May to June 2019, whereas they avoided invertebrates (Fig. S1a). In Paddy B, larvae of $H$. bowringii consistently preferred tadpoles and avoided invertebrates (Fig. S1b).

The model with $\log _{10}$-transformed head width of larvae of $H$. bowringii, site and category of prey was selected as the best model for predicting the $\log _{10}$-transformed body width of prey. Large larvae killed significantly larger prey than small larvae (MLRM, $p<0.0001$, Fig. 4) and the relationships differed significantly for the different categories of prey, such that body width of invertebrate prey was smaller than that of the tadpoles (MLRM, $p=0.014$, Fig.

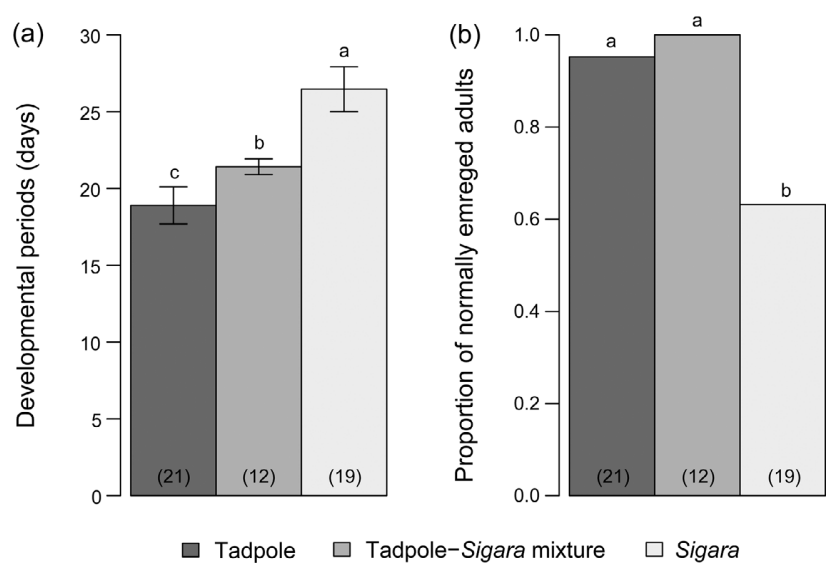

Fig. 5. Comparison of (a) developmental period from hatching to adult emergence and (b) proportion of larvae of $H$. bowringii that emerged as adults in the different treatments in the rearing experiment. Different letters indicate significant differences $(p<0.05)$ between treatments based on (a) Tukey-Kramer HSD test and (b) penalized likelihood ratio test. Numbers in parentheses indicate sample size.

S2) and in Paddy B was bigger than in Paddy A (MLRM, $p$ $=0.003$ ). In addition, the $\log _{10}$-transformed head width of larvae of $H$. bowringii was bigger in Paddy B than Paddy A (ANOVA, $F_{1,134}=8.85, p=0.003$ ).

\section{Effect of diet on the growth and emergence of Hydaticus bowringii}

The total developmental period from hatching to adult emergence differed significantly among treatments (twoway ANOVA, $F_{2,45}=20.69, p<0.0001$, Fig. 5a) and was shortest in the tadpole treatment (Tukey-Kramer HSD test, $p<0.0001)$. On the other hand, sex $\left(F_{1,45}=0.24, p=\right.$ $0.64)$ and the sex $\times$ treatment interaction $\left(F_{2,45}=0.05, p=\right.$ $0.95)$ did not affect the developmental period. In Sigara treatments, larvae consumed $138.0 \pm 13.2$ (mean \pm SD) nymphs and adults of Sigara spp., which is approximately five times the number of tadpoles consumed (mean $\pm \mathrm{SD}=$ $27.7 \pm 2.1$, Table 3 ).

The proportion of normally emerged adults was significantly higher in the tadpole and tadpole-Sigara treatments than in the Sigara treatment (penalized likelihood ratio test, $\chi^{2}=5.9, p=0.049$ ) but did not differ between the sexes (penalized likelihood ratio test, $\chi^{2}=0.52, p=$ 0.47 , Fig. 5b). Adult length differed significantly among sexes and treatments, but the sex $\times$ treatment interaction was not significant (two-way ANOVA, sex: $F_{1,41}=16.75, p$ $<0.0001$; treatment: $F_{2,41}=40.78, p<0.001$; sex $\times$ treatment interaction: $F_{2,41}=0.88, p=0.42$ ). Adult males were smaller in the Sigara treatment than in the other treatments (Tukey-Kramer HSD test, $p<0.01$, Fig. 6a). Size of females in the tadpole treatment was greater than that of wild

Table 3. Number of prey (mean \pm SD) consumed by different instars of larvae of Hydaticus bowringii in the rearing experiment.

\begin{tabular}{|c|c|c|c|c|c|}
\hline Treatment & Prey & 1st instar & 2nd instar & 3rd instar & Total \\
\hline Tadpole & D. japonicus tadpole & $7.0 \pm 1.8$ & $6.5 \pm 2.9$ & $14.2 \pm 2.2$ & $27.7 \pm 2.1$ \\
\hline \multirow{2}{*}{ Sigara-tadpole mixture } & D. japonicus tadpole & $4.5 \pm 1.6$ & $5.5 \pm 2.9$ & $7.2 \pm 2.9$ & $17.2 \pm 3.1$ \\
\hline & Sigara spp. & $0.8 \pm 1.6$ & $8.3 \pm 4.7$ & $14.9 \pm 4.8$ & $23.8 \pm 4.0$ \\
\hline Sigara & Sigara spp. & $11.3 \pm 2.5$ & $20.3 \pm 4.1$ & $106.3 \pm 14.2$ & $138.0 \pm 13.2$ \\
\hline
\end{tabular}




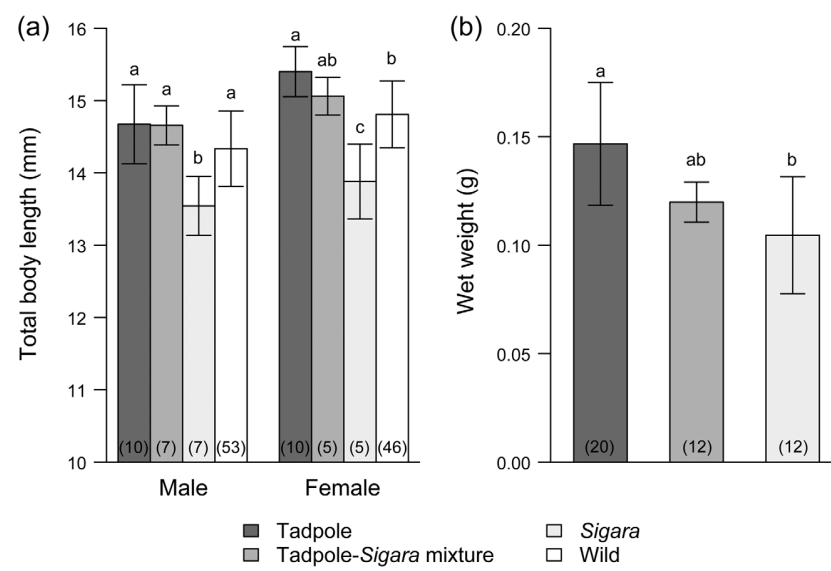

Fig. 6. Comparison of adult $H$. bowringii: (a) total body length and (b) wet weight among treatments in the rearing experiment. Different letters indicate significant differences between treatments based on Tukey-Kramer HSD test. Numbers in parentheses indicate sample size.

individuals (Tukey-Kramer HSD test, $p<0.01$, Fig. 6a). Adult wet weight differed significantly among treatments but not between sexes (two-way ANOVA, sex: $F_{1,41}=0.04$, $p=0.85$; treatment: $F_{2,41}=15.57, p<0.0001$; sex $\times$ treatment interaction: $\left.F_{2,41}=0.82, p=0.45\right)$. Adults were heavier in the tadpole treatment than in the Sigara treatment (Tukey-Kramer HSD test, $p<0.01$, Fig. $6 \mathrm{~b}$ ).

\section{DISCUSSION}

This study revealed that tadpoles are an important source of food for larvae of $H$. bowringii. Larvae of several diving beetles, such as, Acillius, Colymbetes, Cybister, Dytiscus, Hydaticus, Ilybius and Rhantus are known to consume tadpoles (Wells, 2007). Hydaticus larvae are reported feeding on tadpoles in the field and laboratory (Nishida, 2000; Borzée, 2019; Gould et al., 2019). We showed that larvae of $H$. bowringii predominantly feed on frog tadpoles in the field and the inclusion of tadpoles in their diet greatly enhanced larval survival and development in the laboratory. The larvae may eat more insects and other invertebrates than recorded in the field. However, predation events involving small insects may be less detectable because of the shorter handling times associated with small prey. In addition, small prey may not have been detected by us during the night surveys due to visual limitations. For further elucidation, it is necessary to clarify the diet of larvae of $H$. bowringii using isotope analysis and DNA barcoding.

Proportions of different categories of prey in the diet of larvae of $H$. bowringii did not differ among instars as all instars fed mainly on tadpoles. This contrasts with ontogenetic diet shifts reported for Cybister chinensis, in which the first and second instar feed mainly on insects, whereas the third instar feeds equally on insects and vertebrates (tadpoles and fish) (Ohba, 2009b). In general, predator and prey body sizes covary, especially in freshwater generalist predators, which each capture prey of a particular body size (Brose et al., 2006; Nakazawa et al., 2013). The mode of feeding greatly influences the predator-prey body mass allometry in aquatic insects, with sucking predators, such as diving beetle larvae and aquatic bugs, can feed on larger prey than chewing predators of the same size (Klecka \& Boukal, 2013). In addition, the predator-prey body size relationships are weaker in specialist predators that focus on a particular species of prey (Nakazawa et al., 2013). The prey body size increased with increase in the size of the larvae of $H$. bowringii as previously reported for Cybister brevis and C. chinensis (Ohba, 2009a, b). The prey body width was larger in Paddy B than Paddy A, because there were many cases of predation by large larvae in Paddy B than in Paddy A. Although we did not weigh the prey, tadpoles have a greater wet weight than aquatic insects of the same body length (Nakazawa et al., 2013). Therefore, the larvae of the tadpole-eater, $H$. bowringii, can consume larger prey relative to own body size than the larvae of $C y b$ ister chinensis and C. brevis, which are insectivores. Thus, larvae of $H$. bowringii may specialize on tadpoles from the first instar as does the giant water bug, Kirkaldyia deyrolli (Vuillefroy, 1864) (Ohba et al., 2008a; b; Nakazawa et al., 2013; Ohba \& Tatsuta, 2016). Functional morphology and behavioural adaptations of $H$. bowringii for catching tadpoles could be an interesting future study.

Interestingly, we also observed a larva of $H$. bowringii attacking frog eggs in the field. Previous studies report that the larvae of Ilybius and adults of Agabus bipustulatus (Linnaeus, 1767) consume amphibian eggs in laboratory experiments (Resetarits, 1998; Kurdíková et al., 2011) but our observation may be the first example of it occurring in the field. Diving beetle larvae detect prey using visual, tactile, or chemical cues (Culler et al., 2014), which may enable larvae of $H$. bowringii to find frog eggs, although we cannot exclude that such events occur simply at random. In addition, it is reported that Hydaticus parallelus Clark, 1864 and Rhantus pacificus (Boisduval, 1835) oviposit on the surface of frog egg masses and their larvae fed on newly hatched tadpoles (Williams, 1936; Gould et al., 2019). At the sites studied, all larval instars of $H$. bowringii were often observed on frog egg masses (Watanabe, personal observation), which may indicate that adults of $H$. bowringii lay their eggs on or near frog egg masses in order to provide their larvae with an easily available source of prey.

Our results confirm that tadpoles are a suitable prey for the survival and growth of larvae of $H$. bowringii. Ohba et al. (2012) report that the protein content of frogs is greater than that of odonate nymphs. This may affect the survival and growth of larvae of $H$. bowringii. Culler \& Lamp (2009) report that larvae of Agabus disintegratus (Crotch, 1873) are bigger when fed only mosquito larvae or copepods than when fed ostracods and suggest that mosquito larvae and copepods are of poorer nutritional value for $A$. disintegratus than ostracods. On the other hand, the Japanese species of Cybister (C. brevis, C. chinensis, and C. tripunctatus lateralis) are known to prey mainly on insects and odonate nymphs, which are a better prey for the survival and growth of these species than tadpoles (Ohba, 2009a, b; Ohba \& Inatani, 2012). That the diet of different species differs might be due the differences in body size, 
phenology, microhabitat use (Yee et al., 2013), digestive enzymes (Walker et al., 2016) and prey selectivity related to prey nutritional values (Dudová et al., 2019). Further studies are needed to quantify interspecific dietary overlaps of co-occurring diving beetle larvae in paddy fields.

Diving beetle larvae gain most weight and increase in body size during the third instar (Kingsley, 1985; Scholten et al., 2018). Given their smaller size, the Sigara nymphs are of lower nutritional value per individual than are tadpoles for larvae of $H$. bowringii, especially during the third instar, which is indicated by the higher number consumed and longer development in the Sigara treatment than in the tadpole treatment. The relatively minor retardation of growth and lower adult weight in the tadpole-Sigara mixture treatment might have been greater if the first instar larvae were first fed with Sigara nymphs rather than tadpoles. In addition, our results might be at least partly driven by the amount of food provided for the larvae than the type of prey.

\section{Implications for the conservation of Hydaticus bowringii}

Seasonally occurring predators should synchronize their phenology with the occurrence of prey (Evans, 1982; Sota, 1985; Ohba et al., 2008a). The development of $H$. bowringii larvae matched tadpole presence from May to June in 2018 and 2019 at our field sites. In temporary wetlands, such as paddy fields, larval period of aquatic insects needs to be short enough for them to complete their development before the wetland dries out (Williams, 2006). Given their large size, tadpoles are a suitable prey for fast growth and shortening of the larval period. Chironomid larvae were also abundant when larvae of $H$. bowringii were present, however, their availability was low because they are usually buried in the mud.

Recently, frog populations have been declining in Japanese paddy fields because of modern improvements in drainage systems by consolidating fields and habitat fragmentation by urbanization (Natuhara, 2013). In Japan, many paddy fields are flooded between late April and early June and drained for 2 weeks in mid-July to stop the tillering of rice plants (Nisikawa \& Miyashita, 2014). This midseason drainage is considered detrimental for large-sized diving beetles because they cannot pupate before this event (Ichikawa, 2002; Nishihara et al., 2006). In our laboratory experiment, larvae of $H$. bowringii became adults in approximately 19 days in the tadpole treatment and most third instar larvae disappeared in the field in early July. These results indicate that $H$. bowringii may be less affected by the mid-season drainage when tadpoles are available because the adults can escape the drainage by flying to other water bodies. On the other hand, mid-season drainage can negatively affect the tadpoles before they metamorphose (Nisikawa \& Miyashita, 2014), which may indirectly affect $H$. bowringii through prey availability. We conclude that in order to maintain a sufficient abundance of tadpoles it is important to adjust the timing of the mid-season drainage of paddy fields.
Our study indicates that proper maintenance of paddy fields is essential for sustaining populations of $H$. bowring$i i$. We recommend the following practices for the conservation of $H$. bowringii. To maintain amphibian populations in paddy fields, create a traditional earth ditch connected to the paddy fields (Uruma et al., 2012; Taqumori et al., 2020) or dig a V-shaped groove to keep some water in the paddy field (Yabu, 2005). The earth ditch would act as a refuge for tadpoles during the mid-season drainage and a habitat and refuge from predators for frogs (Takeuchi et al., 2019). Aquatic insects such as odonate nymphs can also utilize the earth ditch as a habitat and a refuge during drainage (Yabu, 2005), which may further support other diving beetle species such as Cybister. In fact, Watanabe (2016) reports that the abundance of aquatic beetles and bugs was higher in paddy fields with an earth ditch than those without. The presence of a diversity prey in paddy fields may also prevent intraguild predation occurring in diving beetles.

Forests surrounding paddy fields could also be important for maintaining populations of $H$. bowringii, because the abundance of some frogs (Rana ornativentris and Zhangixalus schlegelii) in paddy fields increases with forest cover (Uruma et al., 2012; Zheng \& Natuhara, 2020). Maintaining forests surrounding paddy fields could also contribute to the conservation of Dytiscus sharpi, which can only complete their development when feeding on the tadpoles of species of Rana (Inoda et al., 2009; Nishihara, 2012).

ACKNOWLEDGEMENTS. We would like to acknowledge T. Yano and S. Nishimura for permision to enter the study site. We also thank K. Kuramitsu (Institute of Agrobiological Sciences) and M. Ikemoto (University of Tsukuba) for constructive comments on the manuscript and data analyses and Editage (www. editage.jp) for editing the English.

\section{REFERENCES}

Abràmoff M.D., Magalhães P.J. \& Ram S.J. 2004: Image processing with imageJ. - Biophotonics Int. 11: 36-41.

Borzée A. 2019: First amphibian behavioural observation from the Democratic People's Republic of Korea: predation of a Dryophytes japonicus tadpole by Hydaticus sp. larvae. - Nat. Conserv. Res. 4: 106-108.

Brose U., Jonsson T., Berlow E.L., Warren P., Banasek-Richter C., Bersier L.F., Blanchard J.L., Brey T., Carpenter S.R., Cattin Blandenie M.-F. et AL. 2006. Consumer-resource body-size relationships in natural food webs. - Ecology 87: 2411-2417.

Chesson J. 1978: Measuring preference in selective predation. Ecology 59: 211-215.

Chesson J. 1983: The estimation and analysis of preference and its relationship to foraging models. - Ecology 64: 1297-1304.

Cobbaert D., Bayley S.E. \& Greter J.L. 2010: Effects of a top invertebrate predator (Dytiscus alaskanus; Coleoptera: Dytiscidae) on fishless pond ecosystems. - Hydrobiologia 644: 103-114.

Culler L.E. \& Lamp W.O. 2009: Selective predation by larval Agabus (Coleoptera: Dytiscidae) on mosquitoes: Support for conservation-based mosquito suppression in constructed wetlands. - Freshw. Biol. 54: 2003-2014. 
Culler L.E., Ohba S. \& Crumrine P. 2014: Chapter 8: predatorprey interactions of dytiscids. In D.A. Yee (ed.): Ecology, Systematics, and the Natural History of Predaceous Diving Beetles (Coleoptera: Dytiscidae). Springer, New York, pp. 363-386.

Dudová P., Boukal D.S. \& KLECKa J. 2019: Prey selectivity and the effect of diet on growth and development of a dragonfly, Sympetrum sanguineum. - PeerJ 7: e7881, 19 pp.

Evans E.W. 1982: Timing of reproduction by predatory stinkbugs (Hemiptera: Pentatomidae): patterns and consequences for a generalist and a specialist. - Ecology 63: 147-158.

Foster G.N. \& Bilton D.T. 2014: Chapter 10: the conservation of predaceous diving beetles: knowns, unknowns and ancedotes. In D.A. Yee (ed.): Ecology, Systematics, and the Natural History of Predaceous Diving Beetles (Coleoptera: Dytiscidae). Springer, New York, pp. 437-462.

Gould J., Valdez J.W., Clulow J. \& Clulow S. 2019: Diving beetle offspring oviposited in amphibian spawn prey on the tadpoles upon hatching. - Entomol. Sci. 22: 393-397.

Heinze G. \& Schemper M. 2002: A solution to the problem of separation in logistic regression. - Stat. Med. 21: 2409-2419.

Heinze G., Ploner M., Dunkler D. \& Southworth H. 2018: Package "logistf". URL: https://cran.r-project.org/web/packages/logistf/logistf.pdf (last accessed 18 Apr. 2020).

ICHIKAWA N. 2002: Declinig factors of Cybister chinensis. Tameikenosizen 36: 9-15 [in Japanese].

Inoda T., Hasegawa M., Kamimura S. \& Hori M. 2009: Dietary program for rearing the larvae of a diving beetle, Dytiscus sharpi (Wehncke), in the laboratory (Coleoptera: Dytiscidae). - Coleopt. Bull. 63: 340-350.

Japan Meteorological Agency 2020: Past Weather Data Download. URL: http://www.data.jma.go.jp/gmd/risk/obsdl/index. php\#!table (last accessed 6 Jun. 2020) [in Japanese].

Johansson A. \& Nilsson A.N. 1992: Dytiscus latissimus and D. circumcinctus (Coleoptera, Dytiscidae) larvae as predators on three case-making caddis larvae. - Hydrobiologia 248: 201213.

KaWAi T. \& TANida K. 2018: Aquatic Insects of Japan: Manual with Keys and Illustrations. 2nd ed. Tokai University Press, Kanagawa, 1730 pp. [in Japanese].

KingSLeY K.J. 1985: Eretes sticticus (L.) (Coleoptera: Dytiscidae): life history observations and an account of a remarkable event of synchronous emigration from a temporary desert pond. - Coleopt. Bull. 39: 7-10.

KLECKA J. \& BouKal D.S. 2012: Who eats whom in a pool? A comparative study of prey selectivity by predatory aquatic insects. - PLOS ONE 7: e37741, 13 pp.

KLECKA J. \& BouKAL D.S. 2013: Foraging and vulnerability traits modify predator-prey body mass allometry: freshwater macroinvertebrates as a case study. - J. Anim. Ecol. 82: 10311041.

Kosmidis I., Konis K., Pagui E.C.K. \& Sartori N. 2020: Package 'brglm2'. URL: https://cran.r-project.org/web/packages/ brglm2/brglm2.pdf (last accessed 22 Sep. 2020).

KuRdíková V., SMOLInSKÝ R. \& Gvoždík L. 2011: Mothers matter too: Benefits of temperature oviposition preferences in newts. - PLoS ONE 6: e23842, 6 pp.

MAFF \& NARO 2012: Survey and Evaluation Manual of Biodiversity Indicators Useful for Agriculture. URL: http://www. naro.affrc.go.jp/archive/niaes/techdoc/shihyo/ (last accessed 18 Apr. 2020) [in Japanese].

Matsui M. \& Maeda N. 2018: Encyclopaedia of Japanese Frog. Bun-ichi Sogo Shuppan, Tokyo, 272 pp. [in Japanese, English abstr.].
MinISTRY OF THE ENVIRONMENT OF JAPAN 2019: Red list of Japan. URL: http://www.env.go.jp/press/files/jp/110615.pdf (last accessed 18 Apr. 2020) [in Japanese].

Mitamura T., Hirasawa K. \& YoshiI S. 2017: The Handbook of Japanese Aquatic Insect. Vol. 1: Coleoptera. Bun-ichi Sogo Shuppan, Toyo, 176 pp. [in Japanese].

Mori M. \& Kitayama A. 2002: Dytiscoidea of Japan. Bun-ichi Sogo Shuppan, Tokyo, $231 \mathrm{pp}$. [in Japanese].

Muka Y. 2014: Organisms Inhabiting in Rice Paddies to be Examined by Painting. Bun-ichi Sogo Shuppan, Tokyo, 80 pp. [in Japanese].

Nakajima J., Hayashi M., Ishida K., Kitano T. \& Yoshitomi H. 2020: Aquatic Coleoptera and Hemiptera of Japan. Bun-ichi Sogo Shuppan, Tokyo, 351 pp. [in Japanese].

Nakazawa T., Ohba S. \& Ushio M. 2013: Predator-prey body size relationships when predators can consume prey larger than themselves. - Biol. Lett. 9: 20121193, 5 pp.

NATUHARA Y. 2013: Ecosystem services by paddy fields as substitutes of natural wetlands in Japan. - Ecol. Eng. 56: 97-106.

Nishida T. 2000: Habitat of Hydaticus conspersus sakishimanus larvae (II). — Gekkan-Mushi 358: 8-9 [in Japanese].

NishiHARA S. 2012: Analysis of freshwater animal community by field experiment and its application to conservation. - Jap. J. Ecol. 62: 179-186 [in Japanese, English abstr.].

Nishihara S., Karube H. \& Washitani I. 2006: Status and conseravtion of diving beetles inhabiting rice paddies. - Jap. J. Conserv. Ecol. 11: 143-157 [in Japanese, English abstr.].

NisikaWa U. \& Miyashita T. 2014: Social-Ecological Restoration in Paddy-Dominated Landscapes. Springer, Tokyo, 308 pp.

Онва S. 2009a: Feeding habits of the diving beetle larvae, Cybister brevis Aube (Coleoptera: Dytiscidae) in Japanese wetlands. - Appl. Entomol. Zool. 44: 447-453.

Онва S. 2009b: Ontogenetic dietary shift in the larvae of Cybister japonicus (Coleoptera: Dytiscidae) in Japanese rice fields. Environ. Entomol. 38: 856-860.

Онва S. 2011: Ecological studies in lentic aquatic insects including rare species: Consideration of their conservations and applied aspects from the predator-prey relationship. — Jap. J. Environ. Entomol. Zool. 22: 39-48 [in Japanese, English abstr.].

OHBa S. \& InATANi Y. 2012: Feeding preferences of the endangered diving beetle Cybister tripunctatus orientalis Gschwendtner (Coleoptera: Dytiscidae). - Psyche 2012: 139714, 3 pp.

Онва S., Izumi Y. \& Tsumuki H. 2012: Effect of loach consumption on the reproduction of giant water bug Kirkaldyia deyrolli: dietary selection, reproductive performance, and nutritional evaluation. - J. Insect Conserv. 16: 829-838.

Онва S. \& TAтsuta H. 2016: Young giant water bug nymphs prefer larger prey: changes in foraging behaviour with nymphal growth in Kirkaldyia deyrolli. - Biol. J. Linn. Soc. 117: 601-606.

Ohba S., Miyasaka H. \& Nakasuji F. 2008a: The role of amphibian prey in the diet and growth of giant water bug nymphs in Japanese rice fields. - Popul. Ecol. 50: 9-16.

Ohba S., Tatsuta H. \& NaKasus F. 2008b: Variation in the geometry of foreleg claws in sympatric giant water bug species: an adaptive trait for catching prey? - Entomol. Exp. Appl. 129: 223-227.

Quintans D. 2019: Package 'electivity'. URL: https://cran.r-project.org/web/packages/electivity/electivity.pdf (last accessed 19 Sep. 2020).

R Core Team 2019 R: A Language and Environment for Statistical Computing. R Foundation for Statistical Computing, Vienna, URL: https://www.r-project.org/ (last accessed 18 Apr. 2020). 
RESETARITS W.J. 1998: Differential vulnerability of Hyla chrysoscelis eggs and hatchlings to larval insect predators. - J. Herpetol. 32: 440-443.

Ripley B., Vanables B., Bates D.M., Hornik K., Gebhardt A. \& FIRTH D. 2020: Package 'MASS'. URL: https://cran.r-project. org/web/packages/MASS/MASS.pdf (last accessed 26 Sep. 2020).

SAIJO H. 2001: Seasonal prevalence and migration of aquatic insects in paddies and an irrigation pond in Shimane Prefecture. — Jap. J. Ecol. 51: 1-11 [in Japanese, English abstr.].

Scholten I., van Kleef H.H., van Dijk G., Brouwer J. \& Verberk W.C.E.P. 2018: Larval development, metabolism and diet are possible key factors explaining the decline of the threatened Dytiscus latissimus. — Insect Conserv. Divers. 11: 565-577.

SOTA T. 1985: Activity patterns, diets and interspecific interactions of coexisting spring and autumn breeding carabids: Carabus yaconinus and Leptocarabus kumagaii (Coleoptera, Carabidae). - Ecol. Entomol. 10: 315-324.

Takeuchi M., Uenishi R. \& Watanabe H. 2019: Habitat use of the Japanese wrinkled frog (Glandirana rugosa) within the Shonan Region, Honshu Island, Japan. — Biodiversity 20: 106-117.

Taqumori R.M., Evans M.J., Soga M., Kobayashi R., Sekiya K., MiYashita T. \& Yoshida K.T. 2020: Modern farming practices in paddy fields negatively affect an endemic frog, Glandirana susurra, in Japan. — Wetlands 40: 1607-1615.

Tate A.W. \& Hershey A.E. 2003: Selective feeding by larval dytiscids (Coleoptera: Dytiscidae) and effects of fish predation on upper littoral zone macroinvertebrate communities of arctic lakes. - Hydrobiologia 497: 13-23.

Tsuzuki Y., Taniwaki A. \& Inoda T. 2003: The Perfect Manuals for Breeding of Aquatic Insects. Data House, Tokyo, 255 pp. [in Japanese].

Uruma H., Kobayashi R., Nihijima S. \& Miyashita T. 2012: Effectiveness of conservation-oriented agricultural practices on amphibians inhabiting Sado Island, Japan, with a consideration of spatial structure. - Jap. J. Conserv. Ecol. 17: 155-164 [in Japanese, English abstr.].

WalKer A.A., Weirauch C., Fry B.G. \& King G.F. 2016: Venoms of heteropteran insects: A treasure trove of diverse pharmacological toolkits. - Toxins (Basel) 8: 1-32.

Watanabe K. 2016: The distribution of aquatic insects (Coleoptera and Hemiptera) in paddies and open ditches in rice fields in southwestern Ehime Prefecture, Japan. - Jap. J. Conserv. Ecol. 21: 227-235 [in Japanese, English abstr.].

WATANABE K. 2017a: Relationships between endangered aquatic insects and paddy. - Nat. Insects 52: 5-8 [in Japanese].

WatANABE R. 2017b: Field observation of hibernating individuals in Hydaticus bowringii and H. grammicus (Coleoptera: Dytiscidae). - Sayabane (New Ser.) 28: 47-48 [in Japanese].

WATANABE R. 2019: Field observation of predation on a horsehair worm (Gordioida: Chordodidae) by a diving beetle larva $C y b$ ister brevis Aubé (Coleoptera: Dytiscidae). - Entomol. Sci. 22: $230-232$.

Watanabe R., Nikkeshi A. \& Yokol T. 2019: Effects of environmental factors in rice paddies and the surrounding landscape on the aquatic insect community. - Jap. J. Conserv. Ecol. 24: 49-60 [in Japanese, English abstr.].

Wells K.D. 2007: The Ecology and Behavior of Amphibians. University of Chicago Press, Chicago and London, $1400 \mathrm{pp}$.

Williams D.D. 2006: The Biology of Temporary Wetlands. Oxford University Press, New York, 352 pp.

Williams F.X. 1936: Two water beetles that lay their eggs in the frothy egg masses of a frog or tree toad. - Pan-Pac. Entomol. 12: $6-7$.
YABU S. 2005: Introduction to the Paddy Field Biotope, Comfortable Rural Environment Created by Rich Organisms. Rural Culture Association Japan, Tokyo, 159 pp. [in Japanese].

Yee D.A., O’Regan S.M., Wohlfahrt B. \& Vamosi S.M. 2013: Variation in prey-specific consumption rates and patterns of field co-occurrence for two larval predaceous diving beetles. - Hydrobiologia 718: 17-25.

Zheng X. \& Natuhara Y. 2020: Landscape and local correlates with two green tree-frogs, Rhacophorus (Amphibia: Rhacophoridae) in different habitats, central Japan. — Landsc. Ecol. Eng. 16: 199-206.

Received April 19, 2020; revised and accepted October 6, 2020 Published online November 9, 2020

(a) Paddy A

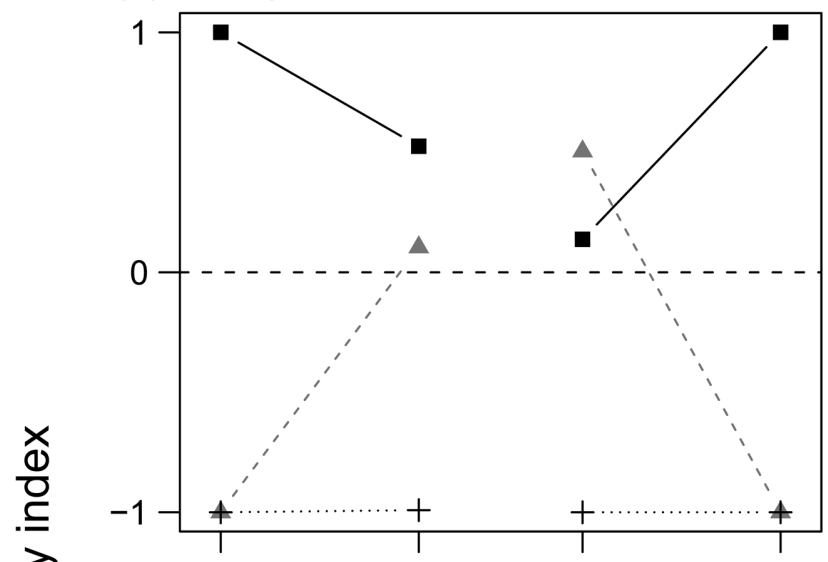

(b) Paddy B

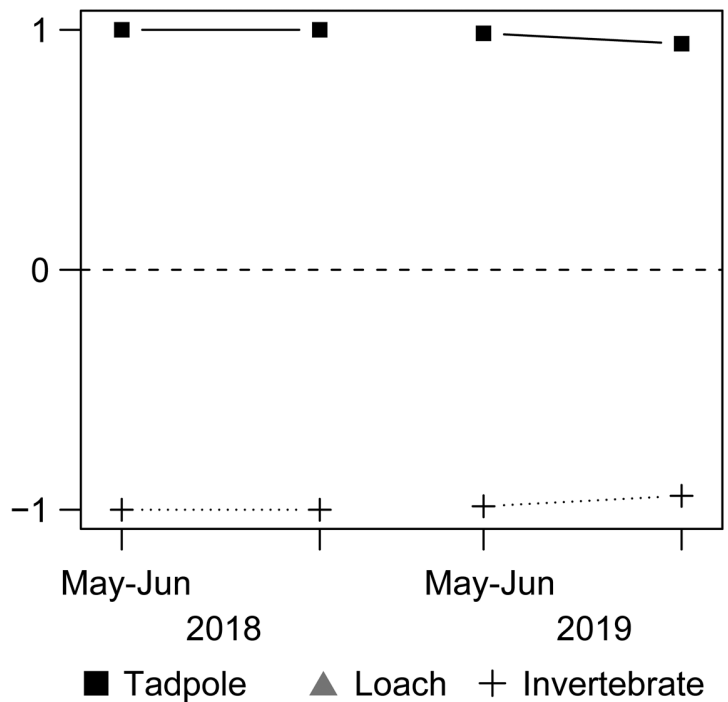

Fig. S1. Prey selectivity by larvae of $H$. bowringii larva at the two sites in 2018 and 2019. Values of the selectivity index $>0$ indicates preference for a particular category of prey and $<0$ indicates avoidance. 


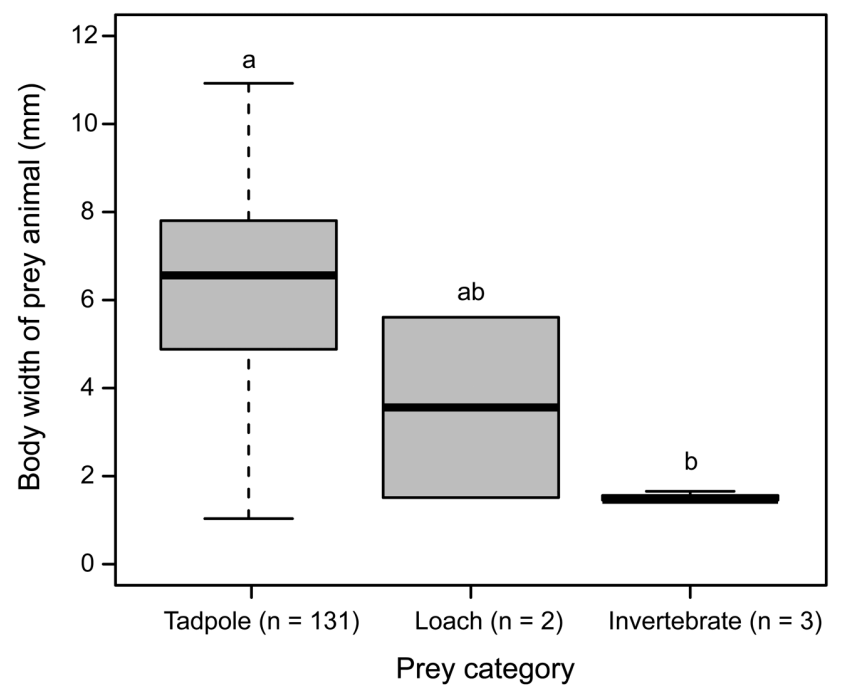

Fig. S2. Comparison of the body width of prey captured by larvae of $H$. bowringii. Different letters indicate significant differences among prey categories (MLRM, $p=0.014$ ). 